\title{
The Living-Dead/Ancestors as Guardians of Morality in African Traditional Religious Thought
}

\author{
Itumeleng Mekoa* \\ Faculty of Humanities, North-West University, South Africa
}

Submission: October 09, 2019; Published: October 29, 2019

*Corresponding author: Itumeleng Mekoa, Research Professor, Indigenous Language Media in Africa Research Entity, Faculty of Humanities, NorthWest University, Republic of South Africa, South Africa

\begin{abstract}
Most studies in African traditional religion have concentrated more on the religious than the moral aspects of the relations between the African and his /her ancestors. The moral guardianship provided by the living dead/ancestors is seldom expressed, yet it is the most important aspect of African life irrespective of their conversion to Christianity or any other religion. Questions may be asked: Do Africans traditionally possess their own indigenous ethical systems? Are such ethical systems and values able to withstand the criticisms of modernity? How, do the living dead/ ancestors act as guardians of morality in traditional African societies? What principles of ethics can we adopt in modern times? Can the African society remain loyal when the living dead/ ancestors are out of the picture and no longer play the role of moral guardians? The purpose of this article is to answer some, if not all, of these questions by examining the role of living dead/ ancestors as moral guardians in African traditional religions. In order to do so, it will be necessary to present an elaborate definition of who the living dead/ ancestors are, what morality is, and what African traditional religion is. I will also examine the critically the methods of ancestral guardianship and their effect in achieving moral standards in African societies.
\end{abstract}

\section{Introduction}

For many years western scholars have defined ancestors as a dead forbear in African traditional religion who has living descendants of a designated genealogical class representing his continued structural relevance. This definition however is not clear and does assist in understanding African traditional thought attached to it. The term "living dead" is the creation of an African scholar Mbiti [1], who prefers it to the common term "ancestor". Mbiti presents the living dead as bilingual, that is, "they speak the language of men with whom they lived until recently; and they speak the language of the spirits and the God to who they are drawing nearer ontologically. Spirits of the living-dead "graduate", into spirits-no longer to be remembered either religiously or morally. Mbiti states: Attention is paid to the living-dead of up to four or five generations, by which time only a few, if any, immediate members of their families would still be alive. When the last person who knew a living-dead also dies, then in affect the process of death is now complete as far as that particular living-dead is concerned [1].

The term "living dead" is thus an all-inclusive one. Mbiti uses it to refer to recently dead children, brother, sisters and other family members who were not in any way ancestors. He strongly advocates the abolition of the two terms "ancestral spirits" and "ancestor" in order to replace them with "spirits" and the "living dead". However, since the term "living dead" has no age distinctions, or regard for social status, it cannot be accurately used in this paper. Instead the terms "ancestors" and "ancestral spirits" must be retained in reference to the qualification of being guardians of morality in African families, clans and tribes.

Not everyone who died achieved ancestral status, although the person could be a living dead. According to Moreau: generally, this was limited to adults, usually male who had children before dying. Depending on their status before death these could be linked relationally to a single family, to the larger clan or age group, or to the whole tribe. Alternatively, they could be linked geographically to a household or to a larger territory. Parenthood before death, as shown above, is vital qualification for the attainment of ancestral status. This explains why the dead continue to play a disciplinary role in the families or communities in which they belong, and why the living respect and obey them: they are still parents, and even in their dead.

\section{Morality in African Thought}

Morality is the distinction between right and wrong. It is the determination of what should be done and what should not be done. Morals deal with behaviours as well as motives. Morality and ethics in Western and non-Western societies have similar importance in that human social and interpersonal behaviour is under the necessity of the adjustment of interests among individuals for attaining the general well-being of the 
community. In all societies the concepts of right and wrong are determined by perceptions of what constitutes the good life for individuals, on the one hand, and the general good of society, on the other. There is a great deal of discussion on what the source of morals is and whether they are objective. Biblically, morals are derived from God's character and revealed to through the Scriptures.

In African traditional religion, behaviour is determined by the various levels of human society such as the family, the clan, and the tribe. Such a community, in African thought, consists of both the living and the dead who maintain a close relationship, with the dead continuing to influence the affairs of the living. KiZerbo also explains: The living was but a microcosm restricted to a certain narrow duty in comparison with the tremendous cohort of those whose shades still peopled the ancestral home or the patriarchal or tribal territory. The African, even when emancipated of his metaphysical beliefs, still gives a large place to his ancestors. For him the famous statement of Renan holds true:" The nation is made up of more dead than living [2]". They look after their descendants' welfare and expect their cooperation in return.

According to Paris [3] the moral vision that constitutes the moral life for Paris is found in four overlapping conceptions of African cosmological and societal thought:

a. The realm of the spirit (inclusive of the Supreme Deity, the sub-divinities, the ancestral spirits), which is the source and preserver of all life.

b. The realm of tribal or ethnic community, which, in equilibrium with the realm of the spirit constitutes the paramount goal of human life.

c. The realm of family, which in equilibrium with the realms of tribe and spirit, constitutes the principal guiding force for personal development, and

d. The individual person who strives to integrate the three realms in his or her soul.

These four ways guide the work of constructing a social ethic that is communal in its praxis for African and Africans in the diaspora according to Paris. Therefore, the realm of the spirits (living dead) interacts with and affects the living or tribal community and vice versa, the familiar unit affects both the spirit realm and tribe, and finally the individual and their actions affects the family, tribe, and spirit. Generally, in Africa, the norm of right or wrong is said to be social custom. As with most other societies of the world, in Africa, the good is usually that which receives the community's approval while the bad is that which the community prohibits or frowns at. While the good actions build up society, the bad ones tear it down. One is social, the other anti-social.

\section{African Traditional Religions}

The traditional beliefs and practices of African people are highly diverse and include various ethnic religions. Generally, these traditions are oral rather than scriptural, include belief in a supreme creator, belief in spirits, use of magic and traditional medicine. The role of humanity is generally seen as one of harmonising nature with the supernatural. Even in these modern times African belief systems have not disappeared despite the invasion of other religions from the West or the East. Although African traditional religions are in constant process of change, the African world view is still informed by traditional ways views and values. According to Willoughby:" ...the aspect of religion which has gripped their (Africans) interests most firmly is that ancestral spirits are active in the affairs of the people, especially as protectors of tribal morality, and are persons with whom men (humans) can deal.

One may conclude this section on definitions by saying that, in African traditional religious practice, morality, just like worship, is an inseparable part of the ancestral cult. They are "generally regarded as righteous and concerned with righteousness" [4]. In Africa, generally, misfortune is not regarded as a natural occurrence or merely bad luck. Instead, every significant misfortune is believed to be caused by a spiritual force strongly motivated in a morally understandable way. Green [4] expresses it this way:" When this world runs its normal, satisfying course, Africans may or may not engage in religious activity. But if this course is disturbed, as it invariably is, Africans seek an explanation in terms of their morality informed spiritual beliefs". According to Green, therefore, Africans therefore understand their experiences mainly in reference to their religious beliefs which are saturated with judgements of right or wrong. In most cases ancestors are mostly "motivated by the moral attitudes and values they previously held as living elders in the community" [4].

\section{Morality in Traditional African societies}

As Africans become more exposed to modern life and change through education, urbanisation and industrialization, individuals are becoming more and more detached from their traditional environment [1]. However, religious belief is still a core component of African life. Mbiti [1] observes, "What people do is motivated by what they believe, and what they believe springs from what they do and experience. So then, belief and action in African traditional society cannot be separated: they belong to a single whole." Individual members of the community each have an obligation of good moral conduct so that whole society may become morally committed.

\section{Courtesy Greetings}

In all African society's persons are expected to exhibit courtesy in the way they address people and the manner of greeting. Courtesy is generally expressed in addressing parents, elder siblings, in-laws and communal elders. Politeness is required even when expressing a different opinion. Rude approaches and replies are condemned, and persistence in them may draw the wrath of the community, both living and dead. Most 
communities have greetings for various times of the day because Africans greet each other as often as they interact. Abstaining from the practice of greeting others usually is a problem. If an individual specially refuses to greet a person while continuing to greet others, he or she is regarded as harbouring ill-will towards that person. It is not uncommon to hear of accusations of wrongs committed against others, evidenced by refusal to greet. It may also a sign that one feels offended by a person or society. As Goba \& Mofokeng [5] point out, "Nothing is more important to Africans than life or being alive. The concern for life or being alive is expressed in the form greeting when they meet. In greeting each other the basic questions are always (around) an inquiry into whether those who meeting are alive, together with their families and friends.

\section{Family Responsibility}

Each member of the African family is part of the composite whole. One must play one's role within the family order to gain the approval of the ancestors and the living elders, who are anyway on the verge of becoming ancestors. A husband is expected to take care of his wife by providing shelter, food and clothing for her. It normally rare to find women expected to provide these, expected where the society traditionally designates these roles of women. A father is expected tom head his family well, except in matrilineal societies. Children are expected to play a role that is assigned to them by the adults in the community. Anyone who fails to fulfil his or her role breaks the claim of co-existence, which is a moral offence.

\section{Marriage and Sexuality}

Africans neither promoted nor condoned celibacy, even among the religious priests. Marriage is always seen as a moral obligation which always ensures the perpetuation of a family, a clan, or tribe from one generation to another. Whoever does not marry is viewed as attempting to cut short the lineage, besides denying the departed the right to become ancestors. It is in everyone's interests that each person marries and have offspring before death. Fortes explains: The deceased's progress in the spirit world is paralleled by that of his son and successors in the world of the living, as they assume his former status. For one to be assured of descendants who will take up one's status after death, ones must marry. And the normally expected sign of a blessed marriage is the conception and birth of a child. The obligation to perpetuate family and tribal lineage is what makes marriage a morally responsibility."

Sexuality is traditionally regulated among the married. Spouses are obliged to fulfil each other's sexual libido, at their convenience. Polygamous marriage is made to take care of the husband's sexual needs in times such as pregnancy and lactation. Sex is mainly for the reproduction of children, but also for ritualistic purposes in some communities. Sex is engaged in on occasions such as planting new seed, harvesting new crops, the marriage of a son or daughter and building a new home. Failure to have sexual intercourse on such occasions may invite chastisement from ancestors. Such sexual contacts are religiously applied for purposes of ritual purity. In most African communities sex is prohibited between parents and children, between brother and sisters, between parents and children and other relations.

\section{Obedience to Authority}

Authority is retained in heads of families, clan chiefs and tribal leaders. They are agents through whom the ancestors enforce moral values in society. They are also seen as potential ancestors. They, therefore, command the highest obedience. Everyone must generate an inherent character of obedience to elder brothers and sisters, elder members of the community and so on. The more obedient one is, the more words of grace he receives from the elderly. One is encouraged to be more obedient to ensure continued good will from both ancestors and living elders, both of who are beneficiaries of one's obedience.

\section{Communal Morality}

Cooperation and co-existence: The maintenance of communal solidarity is of crucial importance for continued existence of any African society. Social order and peace are essential, and sometimes even sacred. Mbiti explains: "This order is conceived of primarily in terms of kinship relationship which simultaneously produces many situations of tension since everybody is related to everybody else and deepens the sense of damage caused by the strain of such tensions [1]. Mbiti explains the kinship system as a vast network embracing everybody in every direction and "...each individual is a brother or sister, father or mother, uncle or aunt, or something else, to everybody else" [1]. This means that every member of the community is a relative, with all the privileges and responsibilities that go with the status.

The importance of the kinship system in Africa is illustrated by the phenomenon that "When two strangers meet in a village (or a town in modern world), one of the duties is to sort out how they may be related to each other, and having discovered how the kinship system applies to them, they behave to each other according to the accepted behaviour set down by the society" [1]. The kinship system promotes a spirit of community in the community. If a person steals a goat, for instance, personal relations are involved at once. The stolen goat may be the property of a 'father,' or 'mother,' or another relative of the thief. The kinship system makes the crime an offense against the community and is punished as such. Mbiti affirms: "Any breach of the accepted code of behaviour is considered evil, wrong or bad, for it is an injury or destruction of the accepted social order and peace. It must be punished by the corporate community of the both the living and the departed ...."

In times of the need the clan system of cooperation provides the necessary closeness and assistance. The whole clan has to be united against a common aggressor. The extended family must discuss and deliberate on raising enough stock for paying the 
required bride price so that one of their sons can acquire a wife. In the modern social and economic structure, such cooperation is evident in payment of fines, raising financial support for students in institutions of higher learning. We can only agree with Mbiti that... "Whatever happens to the individual happens to the whole group to the individual. The individual can only say: "I am, because we are: therefore, I am" [1].

\section{Care of the Widows and Orphans}

This is a key responsibility of the community. Elaborate arrangements are put in place by every community in order that the widow and the orphans may continue to live and function as integral members of the community. In most African tribal groups, where remarrying may not permitted outside of the clan, some form of levirate marriage takes place when a husband passes away. This ensures that procreation continues, as well as the widow's own sexuality, without any immoral and unacceptable sexual behaviour. The various forms of levirate marriage ensure that the widow and the orphans rightfully own the left by the departed. A community that fails to provide land and hosing for its widows loses the respect in the eyes of other communities, besides receiving various forms of punishment from its ancestors. Individuals and families are also obliged by communal requirements to provide food whenever a widow or an orphan needs it, Orphaned children are absorbed into the extended family network.

\section{Justice}

As already pointed out any offense against any member of the community is an offense against the whole community. The community therefore, is responsible for the practice of justice in the community. Leaders must ensure that general law and order is maintained. Murder and violent robbery are severely punished, in most cases by heavy fining and declaring the offender an outcast from the community. Adultery and others sexual offenses demands specific fines paid to the aggrieved party. Leaders make sure justice is done because they represent the ancestors in whatever judgement they make because they represent the ancestors. Stealing from a member of the community is punished. If a parent does any hurtful to his children and which constitute an offense against the children, "...it is the children as such who experience it as an offense, rather it is the community, the clan, the nation, or the departed relatives who are the real objects of offense, since they are the ones with higher status than the parents. Consequently, it is not the children themselves but the offended community or clan or the living- dead who punish the parents" [1].

This aspect of administering justice is because age and status are determinants of who oversees discipline. Parents, due to their age and status, are responsible for the conduct of their children. Elders deal with "disputes and breaches arising from various types of moral harm or offences against custom and ritual" [1]. All punishments are believed to be in this life, here and now. Generally, there is no belief that a person is punished in the hereafter for what he does wrong in this life. Punishment in various forms would be given out for number, robbery, rape, adultery, lying, stealing cruelty (especially towards women), quarrels, bad words, disrespect to persons of a higher status, accusations of sorcery, magic and witchcraft, disobedience of children, and the like. A man who beats or abuses his wife and children is within his rights.

\section{Obligations to Ancestors}

\section{Obedience}

Ancestors to be always interested in the best welfare of the family, the clan, or the tribe. They would like, for instance, that the wealth of the family to be taken care of and used responsibly [6]. Observes that whenever family herds are squandered, “...the ancestors of the will resent it and punish the water." Obedience to ancestors establishes, i.a., a bond of an affection between parent and child. It teaches the child look up to the parent "not only as its earthly protector, but as a friend in the spirit-land" [6]. According to Idowu [7], "The ancestors remain...spiritual superintendents of family affairs and continue to bear their titles of relationship like 'father' or 'mother,"'. Idowu [7] further comments that, "In Africa it is believed that a living father or a living mother ...is endowed with the power to bless or curse on offspring effectively ...it is believed that such in a father or a mother who passed into ancestral world has become infinitely enhanced and continue to be actively effective accordingly.

This gives the ancestral spirit an automatic right to obedience from every descendant. It is, therefore, common practice to listen carefully to the deathbed instructions of an ailing parent, in the hope of strictly obeying the details of such instructions. If a man instructs, as he dies, that the family and must never be sold for any reason, he may severely punish the buyer whom settles on it and force him or her to move out. This ensures security of land tenure by the family.

\section{Appeasement and Affection}

Whenever ancestors act in ways that bring misfortune to the living, the living must appease and show affection to them. The anger of an ancestor is only quenched when a sacrifice of the right type of livestock is made. On the same issue the ancestor may make it easy for his decedents by communicating his or her preference through a dream. Once the demand is fulfilled, normal relationship is restored with the ancestor who can show them his or her appreciation through a blessing of some kind.

Constantly, affection is shown to the ancestors through regular rituals such as the pouring of libation into the soil. People never drink or eat without sharing drink and food with the ancestors. Since it is not clear to the living just how much the ancestors want, sometimes they deliberately neglected for a time on the assumption that they are content. So, "when misfortune strikes, it is really attributed to the ancestors' anger at neglect" [3]. Green points out that, "if a child falls ill, a woman miscarries, or someone suddenly dies, the first instinct of African people is 
to prepare a sacrifice for the ancestors". Such are opportunities for the living to demonstrate selfless devotion to the ancestor's welfare. This will avert further troubles to the descendants, "Once propitiated, they may become benevolently active or even seek help from higher spirits for their kin. But this is usually more than what is required. At a minimum, it is hoped they will feel properly treated and will choose to stay out of the lives of their descendants and cause no further trouble "[3].

These are religious rituals which, however, have strong moral implications on the part of the living. They indicate the seriousness with which the living takes responsibility of peace, good order, and unity within society. Appeasement offering are not merely in order to acquire security for the living: Generous consideration for the needs of ancestors, therefore, is not just a narrowly self-protective measure, nor even a morally understandable expression of gratitude for their past services (although it is both). Above all, it is affirmation of the essential values of self-discipline and respect for authority that form the moral basis for society [3].

\section{Methods of Ancestral Guardianship}

\section{Blessing and Protection}

Ancestors, like parents, confer benefits and exercise benevolence when properly related to. Careful attention to the traditions of the elders result in favour from the ancestors. They strengthen ties in the family. Every kind of blessing is attributed to them. "Healing sickness and protecting from sickness are majorbenefits." [8]. Ancestors usually are credited with such blessings as good health to adults, children, and livestock, protection from danger, a good harvest; increase of children; victory, victory in war, and multiplication of cattle. Rain, especially after a spell of drought, is from them too. Ancestors also help the living by foretelling the future through mediums and mediating between the living and God. Gehman [8] enumerates the following as benefits from ancestors, protection from unjust neighbours, guidance to the living through omens, maintenance of sexual vigour, and the keeping of the cosmological balance. They also reveal new medicines to clan doctors.

\section{Curses and Punishment}

Any evil occurrences may be attributed to ancestors. According to Parrinder [9], "by their attacks and interventions men come to obey the ancestors, and so the social order is maintained." Drought, famine, earthquakes, thunder and lightning may be attributed to the anger of the ancestors. Droughts affect crops, which are their concern as they (crops) grow on ancestral land. Ancestors annoyed at the neglect of their descendants may send special diseases such as insomnia and epilepsy. Although childlessness is sometimes blamed on angry ancestors, it is usually called the work of the witches because ancestors are generally interested in the growth of their own clan. Parrinder [9] quotes from Field, who suggest that the ancestors are unpredictable: "it is their injure and their sudden attacks on the routine of the well-being that make men aware of them rather than their benefit guardianship [10-15]."

Ancestors have a powerful moral role and only inflict trouble only when they are personally neglected. They also enforce lineage and social rules [3]. Green says that, "Forms of conduct that disturb the group's peace -enmity, quarrelling, incest, failure of specific kinship duties like the support of orphans or the proper distribution of bride wealth- can be severely punished by the ancestors through infliction of sickness or death. Curses are greatly feared, and everyone does what he can do in order to avoid them. An elder, while still alive, may curse his own sons if they behave contrary to the norms of society [16-18]. It behoves the son to correct the wrongs committed before his father's death in order to be free from curse and enjoy normal life."

\section{Communication}

Regular communication takes place between the living and the dead, in order to that the living may carry on their activities without offending the ancestors. The living consults the ancestors whenever there is a crisis in the community. This they do by consulting a medium who is able, effectively, to acquire accurate information from the ancestral spirits. The answers received from the medium are put into effect so that the crisis is resolved. From time to time ancestors choose to communicate their wishes without necessarily have been consulted. This happens when ancestors wish to communicate an issue that would be of greatest help to the community. According to Mbiti [1], "Some diviners and medicine men through dreams or appearance from the spirits and the living- dead, concerning diagnosis, treatment and prevention of diseases. "The ancestors are portrayed as caring for the present and future well-being of society, hence their positive message [19-22].

There are, however, instances in which the communication from ancestors is negative and cause harm to the living. Such occurrences take place when, for instance, the living-dead are not properly buried, when they have a grudge, are neglected or when not obeyed. They may communicate their anger by taking revenge or punishing the offenders. Such punishment act as messages intended to remind the living of the probable misconduct. Gehman [8] discusses five means of communication, apart from mediums, used by the ancestors to communicate with the living. First are apparitions, in which ancestral spirits appear in non-material but visible form. The living can recognize the form of his ancestor by his appearance and clothing. Ancestors also communicate through unexpected fire, trouble and spirit possession.

\section{Conclusion}

In African traditions, ethics and religion are closely connected, to the extent that the practice of either results in the fulfilment of the other. People want to live in harmony with their departed relatives and experiences peace among themselves. This anticipation finds fulfilment in regular normalizing of 
relations with the ancestors. Traditional laws that govern normal life among the living are enforced by the elders, both the living and the departed. Ancestors are factors of social cohesion. There is thus a notable, though not fundamental, difference between ethical systems developed in literate religious faiths and African practice of morality. African moral values such as respect, courtesy expressed in greetings, hospitality, generosity, caring for widows, taking in orphans, cooperation, unity, obedience, and general care for another, can very well be practiced not only by African converts to Christianity and other faith, but also by other races who value humanity and proper relationships.

\section{References}

1. Mbiti JS (1969) African Religions and Philosophy. Heinneman educational Books, London, UK.

2. Ki-Zerbo T (1976) African Personality and new African Society. In: Pan-Africanism Reconsidered. American Society of African literature.

3. Peter J Paris (1995) The Spirituality of African Peoples: The Search for a Common Moral Discourse. Fortress Press, Minneapolis, USA, p. 19.

4. Green RM (1988) Religion and Moral Reason. Oxford University Press Books, New York, USA.

5. Goba BC, Mofokeng TA (1985) Theological Ethics (Ethics of Non-Christian Religions and Ideologies): Only Study Guide for TEB 302-H. University of South Africa, Pretoria, South Africa.

6. Willoughby WC (1928) The Soul of the Bantu. Garden City, Doubleday, Doran and Company, Inc., New York, USA.

7. Idowu EB (1975) African Traditional Religion: A Definition. Maryknoll, Orbis Books, New York, USA.

8. Gehman RJ (1985) Ancestor Relations among Three Societies in Biblical Perspective. Unpublished Doctoral Dissertation. Fuller Theological Seminary, USA.

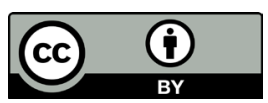

This work is licensed under Creative Commons Attribution 4.0 License DOI: 10.19080/GJAA.2019.10.555799
9. Parrinder EG (1968) African Traditional Religion, SPCK, London, UK.

10. Dickson KA, Elingworth P (1969) Biblical Revelation and African Beliefs. Lutherwork Press, London, UK.

11. Eitel K (1986) Transforming Culture. Evangelical Publishing House, Nairobi, Kenya.

12. Hans-Egil H (1974) Luo Religion and Folklore. Scandinavian University Books, Oslo, Europe.

13. International African Institute (1972) African Systems of Thought. Oxford University Press, London, UK.

14. Jacobs DR (1975) The Culture Themes and Puberty Rites of the Akamba: A Bantu Tribe of East Africa. Unpublished Doctoral Dissertation, New York University Press, USA.

15. Kenyatta J (1931) Facing Mount Kenya: Heinneman Educational Books, London, UK.

16. Mbiti JS (1975) The Prayer of African Religion. S.P.C.K, London, UK

17. Moreau AS (1990) The World of the Spirits: A Biblical Study in the African Context. Evangel Publishing House, Nairobi, Kenya.

18. Nolen B (1967) Africa is People. E.P. Dutton and Co., Inc., New York, USA.

19. Norbeck E (1985) Ancestor Worship. Encyclopaedia Britannica, Macropaedia, 1: 835-837.

20. Ochieng W (1979) People Round the Lake. Evans Brother, Ltd, London, UK.

21. Ocholla-Ayayo ABC (1976) Traditional Ideology and ethics among the Southern- Lou. The Scandinavian Institute of African Studies, Uppsala, Europe.

22. Webster N (1060) Webster's new Twentieth Century Dictionary of the English Language. Cleveland/ The World Publishing Company, New York, USA.

\section{Your next submission with Juniper Publishers} will reach you the below assets

- Quality Editorial service

- Swift Peer Review

- Reprints availability

- E-prints Service

- Manuscript Podcast for convenient understanding

- Global attainment for your research

- Manuscript accessibility in different formats

( Pdf, E-pub, Full Text, Audio)

- Unceasing customer service

Track the below URL for one-step submission

https://juniperpublishers.com/online-submission.php 